\title{
RADIOCARBON
}

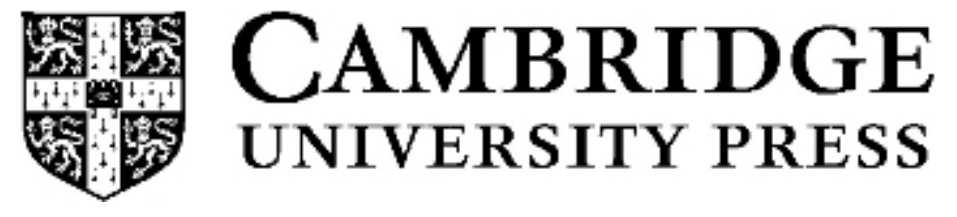

\section{MARINE BIVALVE FEEDING STRATEGIES AND RADIOCARBON AGES IN NORTH EAST ATLANTIC COASTAL WATERS}

\begin{tabular}{|r|l|}
\hline Journal: & Radiocarbon \\
\hline Manuscript ID & RDC-RES-2018-0155.R3 \\
\hline Manuscript Type: & Research Article \\
\hline Author: & 29-Apr-2019 \\
\hline Complete List of Authors: & $\begin{array}{l}\text { Lo Giudice Cappelli, Elena; University of St Andrews, School of } \\
\text { Geography and Sustainable Development } \\
\text { Austin, William; University of St Andrews, Geography \& Sustainable } \\
\text { Development }\end{array}$ \\
\hline Keywords: & Radiocarbon, Diet, Paleoecology \\
\hline & \\
\hline
\end{tabular}

\section{SCHOLARONE" \\ Manuscripts}




\title{
EDMARINE BIVALVE FEEDING STRATEGIES AND RADIOCARBON AGES IN NORTHEAST ATLANTIC COASTAL WATERS
}

\author{
Elena Lo Giudice Cappelli ${ }^{1^{*}} \bullet$ William E N Austin ${ }^{1,2}$ \\ ${ }^{1}$ School of Geography and Sustainable Development, University of St Andrews, St Andrews KY16 9AL, \\ Scotland, UK \\ ${ }^{2}$ Scottish Association for Marine Science, Scottish Marine Institute, Oban, Scotland, UK \\ Corresponding author. Email: elgc@st-andrews.ac.uk.
}

[Notes to typesetter. Running header author: E Lo Giudice Cappelli \& W E N Austin

Running header title: Marine Bivalve ${ }^{14} \mathrm{C}$ Ages]

\begin{abstract}
Marine mollusk shells have been extensively used to provide radiocarbon $\left({ }^{14} \mathrm{C}\right)$-based chronologies in paleoenvironmental and archaeological studies, however uncertainties in age measurements are introduced because secondary factors such as vital effects and diet may influence ${ }^{14} \mathrm{C}$ incorporation into these shells. Deep burrowing and deposit feeding mollusks, in particular, may incorporate "old" carbon resulting in apparently older ages than their contemporary environment. In this study, we present paired ${ }^{14} \mathrm{C}$ and stable isotope $\left(\delta^{13} \mathrm{C}\right.$ and $\left.\delta^{18} \mathrm{O}\right)$ measurements for nine species of known-age bivalves having different feeding strategies and collected in six localities around the NE Atlantic. We exclude potential "old" carbon contamination in these known-age mollusk shells, acquire a better understanding of local ecology and provide an improved context for the environmental interpretation of ${ }^{14} \mathrm{C}$ ages. Our results indicate that, in the NE Atlantic, marine mollusk-derived ${ }^{14} \mathrm{C}$ ages provide a reliable basis for environmental and archaeological investigation, independently of vital effects and differences in microhabitats, feeding strategies and sample location-all of which are apparent from stable isotopes.
\end{abstract}

KEYWORDS: diet, mollusks, paleoecology, radiocarbon.

\section{INTRODUCTION}

Marine mollusk shells can be a very useful source of palaeoarchives in coastal and continental shelf waters, particularly with regard to their stable isotopes $\left(\delta^{13} \mathrm{C}\right.$ and $\delta^{18} \mathrm{O}$ ) (e.g. Simstich et al. 2005a, 2005b; McConnaughey and Gillikin 2008; Mettam et al. 2014; Reich et al. 2015) and trace metal composition (Mg/Ca, Sr/Ca) (e.g. Batenburg et al. 2011; Warter et al. 2015). The shell composition of many mollusk species is likely to represent ambient seawater conditions and can be used to trace the physical and chemical properties of the surrounding waters. Furthermore, mollusk carbonate can provide a direct chronology of environmental change through radiocarbon $\left({ }^{14} \mathrm{C}\right)$ dating.

The disequilibrium between marine and atmospheric ${ }^{14} \mathrm{C}$ concentrations requires that the resulting marine reservoir age must be taken into account when using marine sourced samples to construct a chronology. Marine reservoir ages have been generated for a number of sites (Cage et al. 2006; Rick et al. 2012; Hadden and Cherkinsky 2015, 2017a, 2017b) but further uncertainty is introduced as mollusks inhabit a range of ecological niches. The usual assumption is that shell carbonate is precipitated from dissolved inorganic carbon in seawater; however, shell formation can be influenced by secondary factors such as metabolic processes (vital effect) and feeding strategies (DeNiro and Epstein 1978; Tanaka et al. 1986; Gillikin et al. 2006; McConnaughey and Gillikin 2008). This may be 
of significance in the case of deep burrowing and deposit feeding mollusks, as they can incorporate in their shells carbon from old calcareous sediments resulting in apparently older ages than the true age of seawater dissolved inorganic carbon (e.g. Cage et al. 2006; Mangerud et al. 2006). Additionally, a recent study reported that old, but bioavailable organic matter found in arctic aquatic environments due to thawing of permafrost (yedoma) can be a source of old carbon in the diet of aquatic organisms, causing an overall "aging" effect (Guillemette et al. 2017). Several studies purport to find apparent ${ }^{14} \mathrm{C}$ age differences between contemporaneous mollusk specimens (e.g. Forman and Polyak 1997; Hogg et al. 1998; Yoneda et al. 2000; Rick et al. 2012; England et al. 2013; Jull et al. 2013; Hadden and Cherkinsky 2015, 2017a, 2017b); whereas others claim that no significant age difference is observed between species from different ecological settings (Harkness 1983; Berkman and Forman 1996; Eiríksson et al. 2004; Ascough et al. 2005; Tisnérat-Laborde et al. 2010).

Similarly, the impact of vital effects and feeding strategies on stable isotopes is still under debate. Some studies report high internal variability in marine mollusk stable isotopes that would prevent their use as robust environmental proxies (e.g. Gillikin et al. 2006); whereas others used stable isotopes to identify palaeoenvironments and ecological processes within these environments (e.g. Mettam et al. 2014; Reich et al. 2015).

To assess the reliability of ${ }^{14} \mathrm{C}$ ages and stable isotopes, we analyzed 9 species of known-age marine bivalves collected in 6 localities around the NE Atlantic coast (Figure 1). By comparing live-collected pre-bomb marine bivalve ${ }^{14} \mathrm{C}$ ages and stable isotopes from (i) replicate samples of a single species from the same locality (ii) the same species at different localities and (iii) different species at the same locality, we examined in situ, intra-species and inter-species variability in a wider context than has been previously undertaken.

\section{MATERIAL AND METHODS}

\section{Area of Study}

The Fishery Board of Scotland conducted a survey of bottom fauna in the northern part of the North Sea and to the north and west of Scotland during the years 1922-1925 (Stephen 1934). The current study focuses on six of these sites: Shetland (Gruting Voe), Cromarty Bay, Forth (St Andrews Bay), Minch (Loch Erisort), Hebrides (Loch Leurbost) and Faroes.

Grunting Voe is located in the southwest of Shetland (Figure 1). Two main types of soil are present in this catchment: peat and organic soils, both poorly draining. A few rivers and streams discharge in Grunting Voe, however freshwater influence in the voe is generally very low. This, together with an overall small tidal range, leads to wind-driven currents locally, with wind typically blowing from the south (Cefas 2010a).

Figure 1 Location map of samples analyzed in this study (stars), and circulation map representing major current pathways after Austin et al. (2012) and Baxter et al. (2011). Black arrows indicate North Atlantic current, green arrows indicate coastal currents. Sea surface salinity and temperature data are from GIN sea regional climatologies (Seidov et al. 2018). (Please see electronic version for color figures.) 
Cromarty Bay is a shallow, enclosed basin adjacent to the Moray Firth on the east coast of Scotland (Figure 1). Two types of soils are characteristic of the area: peaty soils and most predominantly humus iron podzols, the latter being freely draining and potentially reducing runoff. The catchment area includes one large river (River Conon) and smaller watercourses that seasonally supply freshwater to the Cromarty Bay. Predominant winds are from the north east and, in combination with density (freshwater) flows, can drive local currents. Tidal energy is strong in the Cromarty Firth, but tidal currents seems to slow down in proximity of the Bay where a sand bar is deposited (Cefas 2010b).

The Forth is situated on the eastern coast of Scotland bathing the city of St Andrews after which the Bay takes its name (Figure 1). Nowadays, this is an urbanized area and most of the land is arable, improved grassland. In proximity of the Forth Estuary, prevailing currents are tidal and freshwater inputs have a very marginal influence on local hydrography. Local currents are overall relatively weak and the Forth is more of a coastal/marine environment than an estuary (Cefas 2013).

The Minch bathes the eastern coast of the Isle of Lewis in the Outer Hebrides (Figure 1). The catchment area of Loch Erisort is dominated by peaty soils with the sparse presence of organic and brown forest soils. Currents can be highly impacted by seasonal freshwater inputs from local streams resulting in density flows, but are generally quite weak. The rough topography of the seafloor may enhance local currents close to constrictions, and wind-driven currents usually prevail over tidal energy (Cefas 2010c).

The Hebrides site, Loch Leurbost, is also situated on the eastern coast of the Isle of Lewis, just north of the Minch site (Figure 1). Two types of soils characterize this loch: brown forest soils (freely draining) on the northern coast and peaty soils (poorly draining) inland to the north of the loch and along the southern coastline. Currents are generally weak but can be channeled by changes in local bathymetry owing the presence of the island of Tannaraidh and other smaller islands at the mouth of loch as well as sills between the head, inner and outer basins. Additionally, density flows can occur seasonally following heavy rain periods and enhanced riverine inputs (Cefas 2011).

The Faroe Islands are situated between Iceland, Norway and Scotland (Figure 1), in a region where Atlantic Ocean waters enter the Nordic Seas. A persistent tidal flow encompasses Faroes' shelf waters separating this coastal environment from the open ocean. Faroes coast is jagged by many fjords and consists of steep cliffs and mountainous plateaus, which are part of the North Atlantic basalt region that formed in the Tertiary during a period of intense volcanism (Gillespie and Clague 2009).

Overall, these six sites are either calm depositional fjordic environments (Shetland, Minch and Hebrides) or low energy enclosed coastal basins sheltered from the open ocean (Cromarty, Forth and Faroes), with relatively stable annual sea surface temperatures and salinities (Figure 1). With the exception of the Forth, there are no limestones in the area of study which means that we can exclude potential "old" carbon contaminations due to ${ }^{14} \mathrm{C}$-depleated dissolved inorganic carbon in all other sites. A fairly uniform water mass bathe the UK continental slope as its steepness limits the amount of deep North Atlantic waters entering the shelf (Inall et al. 2009; Baxter et al. 2011). To the west, the main water mass stems from the warm and saline Eastern North Atlantic Central Water, which travels northward along the west coast of Scotland (Inall et al. 2009). Similarly, the Scottish Coastal Current also travels northward carrying waters from the Irish and Clyde Seas and experiencing a slight freshening in proximity of the fjords peppering the coast of western Scotland (Inall et al. 2009; Baxter et al. 2011) (Figure 1). To the east, the circulation in the North Sea is typically anti-clockwise and fresh 
and cool North Atlantic waters enter this region from Orkney and Shetland and along the Norwegian Trench (Baxter et al. 2011) (Figure 1).

\section{Sampling Strategy}

Samples were collected from both intertidal areas by hand-sampling a fixed volume $(0.5 \times 0.5 \times 0.15$ $\mathrm{m})$, or from below the low watermark using a Petersen grab ( $0.1 \mathrm{~m}^{3}$ volume). Material was washed through $2 \mathrm{~mm}$ (intertidal samples) and $1.5 \mathrm{~mm}$ (grab samples) mesh sieves, before counting and identification of the mollusk fauna. The collection now resides with the National Museum of Scotland (reg. no.: NMSZ 1951.19), and specimens are stored dry in airtight glass vials or sealed polyethylene bags. Table 1 lists the nine species analyzed in this study and their ecologies and habitats; Table 2 includes the samples available for stable isotopes and ${ }^{14} \mathrm{C}$ analysis. Five of the six sites contain more than one of these species, typically including a combination of suspension feeding, deposit feeding or mixed feeding species (Table 2). No records exist to conclusively indicate all specimens were livecollected, although this was certainly the intent of the original project, and so the remote possibility exists for some of the material to be reworked and potentially diagenetically altered. To improve the likelihood of the samples being live on collection, all samples analyzed were articulated bivalves with intact pereostracum, and frequently with internal organic matter still present.

\section{[Insert Tables 1 and 2 about here.]}

\section{Stable Isotopes and Radiocarbon Analyses}

Samples were weighed and placed in a $0.2 \mathrm{M} \mathrm{HCl}$ solution overnight to ensure dissolution of about $20 \%$ of the outer carbonate. This pre-treatment also loosened any pereostracum adhering to the outer shell, which was mechanically removed along with any other surficial organic material attached to the shell. Samples were washed repeatedly with distilled water to remove any remaining acid, then freezedried and finally ground prior to analysis. Subsamples were taken for stable isotope mass spectrometry and ${ }^{14} \mathrm{C}$ analyses. Stable isotopes measurements were performed at the University of St Andrews in a Gasbench autosampler coupled to a ThermoScientific Finnigan Delta plus mass spectrometer. Standard reference materials (IAEA C2 travertine and Iceland Spar calcite) were analyzed along with the samples for quality control with a calcite acid fractionation factor of 1.01025 at $25^{\circ} \mathrm{C}$ (Sharma and Clayton 1965) and internal precision (zero enrichment test) of $\pm 0.05 \%$ for $\delta^{13} \mathrm{C}$ and $\pm 0.1 \%$ for $\delta^{18} \mathrm{O}$ measurements. For accelerator mass spectrometry ${ }^{14} \mathrm{C}\left(\mathrm{AMS}{ }^{14} \mathrm{C}\right.$ ) analysis, samples were hydrolyzed to $\mathrm{CO}_{2}$ using $100 \% \mathrm{H}_{3} \mathrm{PO}_{4}$ (phosphoric acid), and then gas cryogenically trapped into sealed quartz-glass tubes. Age measurements were made at the NERC Radiocarbon Laboratory, East Kilbride (SUERC).

\section{Statistical Treatment of Data}

We subdivided our dataset in three subsets to investigate: in situ variability (same species-same locality), intra species variability (same species-different localities) and inter species variability (different species-same locality). Note that replicate samples used to discuss in situ variability refer 
to individual samples, not repeat measurements on the same shell. We used the method detailed in Ward and Wilson (1978) to test for homogeneity within groups of ${ }^{14} \mathrm{C}$ measurements.

To understand whether ages are comparable and thus can be combined together, we determined the pool mean $\left(A_{p}\right)$ of each subset of measurements

$A_{p}=\Sigma\left(A_{i} / S_{i}^{2}\right) / \Sigma\left(1 / S_{i}^{2}\right)$

and then calculated

$T=\Sigma\left(A_{i}-A_{p}\right)^{2} / S_{i}^{2}$

where $A_{i}$ is the measured ${ }^{14} \mathrm{C}$ age and $S_{i}$ is the associated $1 \sigma$ error. When T was less than the critical value for $\alpha=0.05$, then ${ }^{14} \mathrm{C}$ ages are not statistically different and can be combined together.

\section{RESULTS AND DISCUSSIONS}

\section{In situ Variability: Same Species-Same Locality}

For the Shetland dataset, we have replicate samples only of $A$. nitida (Table 3 ). Based on three measurements ( 5 shells were measured in total), $\delta^{13} \mathrm{C}$ varies from -0.1 to $0.1 \%$, $\delta^{18} \mathrm{O}$ varies between 2.7 and $3.2 \%$ and ${ }^{14} \mathrm{C}$ dates vary from 467 to $510 \mathrm{BP}$ (Figures 2 and 3 ).

\section{[Insert Table 3 about here.]}

Figure 2 Stable isotopes discriminate between different ecological settings. Circles mark mixed feeders, squares suspension feeders, triangles deposit feeders and diamonds symbiont bearers. Samples from Shetland are in blue, from Cromarty in pink, from Forth in yellow, from Minch in green, from Hebrides in red, and from Faroes in black. Error bars represent the instrumental errors on $\delta^{18} \mathrm{O}$ and $\delta^{13} \mathrm{C}$.

Figure $3{ }^{14} \mathrm{C}$ measurements. a) In situ variability. b) Spatial variability in Abra spp. c) Spatial variability in Nucula spp. d) Inter species variability; stars mark average ${ }^{14} \mathrm{C}$ age at each location regardless of species. Red lines mark the average ${ }^{14} \mathrm{C}$ age of each subset of data, empty symbols mean no replicate measurement was available. Error bars represent $\pm 1 \sigma$ error of ${ }^{14} \mathrm{C}$ ages.

For the Forth dataset, duplicate samples of $A$. alba ( 5 shells), C. gallina (4 shells) and N. turgida (4 shells) were analyzed (Table 3). For $A$. alba, $\delta^{13} \mathrm{C}$ varies between 0.1 and $0.3 \%, \delta^{18} \mathrm{O}$ varies from 2.1 to $2.4 \%$ and ${ }^{14} \mathrm{C}$ ages vary from 496 to $517 \mathrm{BP}$ (Figures 2 and 3 ).

For C. gallina, $\delta^{13} \mathrm{C}$ varies between 0.1 and $0.2 \%$, $\delta^{18} \mathrm{O}$ varies from 0.4 to $0.8 \%$ and ${ }^{14} \mathrm{C}$ dates vary between 417 and $464 \mathrm{BP}$ (Figures 2 and 3).

For N. turgida, $\delta^{13} \mathrm{C}$ varies between 0.3 and $1.3 \%$, $\delta^{18} \mathrm{O}$ varies between 2.0 and $3.0 \%$, and ${ }^{14} \mathrm{C}$ ages vary between 447 and $462 \mathrm{BP}$ (Figures 2 and 3 )

For the Minch dataset, we have duplicate samples of A. alba (4 shells) and T. flexuosa ( 3 shells) (Table 3). For $A$. alba, $\delta^{13} \mathrm{C}$ varies between -0.9 to $-0.7 \%$, $\delta^{18} \mathrm{O}$ varies from 2.3 to $2.5 \%$, and ${ }^{14} \mathrm{C}$ dates vary from 448 to 552 BP (Figures 2 and 3 ).

For $T$. flexuosa, $\delta^{13} \mathrm{C}$ varies between -5.5 and $-5.4 \%$, $\delta^{18} \mathrm{O}$ varies from 1.4 to $1.5 \%$, and ${ }^{14} \mathrm{C}$ ages vary between 506 and 532 BP (Figures 2 and 3). 
For the Faroes dataset, we have duplicate measurements only of $N$. nucleus ( 5 shells) (Table 3 ). $\delta^{13} \mathrm{C}$ varies between 1.3 and $1.7 \%$ o, $\delta^{18} \mathrm{O}$ varies around $2.8 \%$ (Figure 2 ) and no duplicate ${ }^{14} \mathrm{C}$ date is available for this sample.

In general, in situ variability in stable isotope measurements is low due to the precision of the measurements, yet statistically significant (Figure 2). In Figure 2 we reported individual stable isotope measurements to show the overall variability of the dataset. Four groups can be identified based on mollusks' feeding strategies and shells stable isotope composition: symbiont bearer, suspension feeders, mixed feeders and deposit feeders (Figure 2-different symbols shape). The highest in situ variability in $\delta^{13} \mathrm{C}$ measurements was found in $N$. turgida and $N$. nucleus possibly because they are deposit feeders that can incorporate into their shells carbon from different sources (Yonge 1939; Ruppert et al. 2004; Cage et al. 2006; Mangerud et al. 2006). Notably, terrestrial organic matter is enriched in ${ }^{12} \mathrm{C}$ from soils resulting in lower $\delta^{13} \mathrm{C}$ values than marine organic matter (e.g. Ficken et al. 1998; Balasse et al. 2005; Schmidt and Gleixner 2005; Marconi et al. 2011; Schiener et al. 2014). Similarly, A. alba $\delta^{13} \mathrm{C}$ in situ variability is statistically significant albeit small (Figure 2). Most likely this is the result of $A$. alba being a mixed feeder that can process a large volume of sediments to feed on detritus when it does not suspension feed (Dame 1996). The presence of symbionts seems to drive the unique $\delta^{13} \mathrm{C}$ of $T$. flexuosa (Mangerud et al. 2006), whereas no in situ variability is observed in the suspension feeder C. gallina $\delta^{13} \mathrm{C}$ (Figure 2). In situ variability in $\delta^{18} \mathrm{O}$ is significant in A. alba, C. gallina and $N$. turgida from Forth and in $A$. nitida from Shetland. We suggest that in situ changes in $\delta^{18} \mathrm{O}$ could be either due to changes in microhabitats or to differences in time-averaging among individuals. These mollusks are infaunal burrowers able to move within the sediments depending on food availability and changes in environmental conditions. This implies that the measured $\delta^{18} \mathrm{O}$ possibly reflects microhabitat preferences. Additionally, five specimens of $A$. nitida (Shetland), four of $C$. gallina, five of $A$. alba and four of $N$. turgida (Forth) were ground together before being measured, which means that the observed variability could also relate to seasonal changes in sea water conditions over a number of years, depending on the individual specimen's lifespan. While these are known to be shortlived species, no information is available on shells' lifespan, thus we have no means to check for differences in ontogenetic ages.

In contrast, no significant in situ variability is observed in ${ }^{14} \mathrm{C}$ ages and all shells are the same age within the $\pm 1 \sigma$ error, with the exception of $A$. alba from Minch (Table 3 ). However, all shells are the same age when considering the $\pm 2 \sigma$ error on ${ }^{14} \mathrm{C}$ ages, and no "old" carbon effect was observed in the Forth dataset suggesting lack of weathering of the Carboniferous limestone (Figure 3a).

\section{Intra-Species Variability: Same Species-Different Location}

The mixed feeder Abra spp. (A. alba and A. nitida together) is present at five of the six locations: Shetland, Cromarty, Forth, Minch and Hebrides (Figure 1), thus enabling inter-locality comparison of stable isotope and ${ }^{14} \mathrm{C}$ measurements. Based on all five localities, spatial variability is significant in Abra spp. stable isotopes (Figure 2 -circles), whereas it does not affect ${ }^{14} \mathrm{C}$ ages within the $\pm 1 \sigma$ level of uncertainty (Figure 3b; Table 4).

[Insert Table 4 about here.] 
Nucula spp. is present at three of the six locations: Forth, Minch and Faroes (Figure 1), allowing to assess spatial variability of stable isotope and ${ }^{14} \mathrm{C}$ measurements in deposit feeders. Considering all three localities together, spatial variability is significant in Nucula spp. $\delta^{13} \mathrm{C}$ and $\delta^{18} \mathrm{O}$ (Figure 2triangles), whereas it does not affect ${ }^{14} \mathrm{C}$ ages within the $\pm 1 \sigma$ level of uncertainty (Figure 3c; Table 5).

\section{[Insert Table 5 about here.]}

In summary, marine bivalve stable isotopes record seasonal changes in local environments and can be a useful source of palaeoarchives in coastal and continental shelf waters (Figure 2). The spread in $\delta^{18} \mathrm{O}$ measurements in Abra spp. seems to reflect the temperature gradient between the sites with colder temperature in Shetland (high $\delta^{18} \mathrm{O}$ ) and warmer temperature at the Hebrides (low $\delta^{18} \mathrm{O}$ ) (Figures 1 and 2). The range of $\delta^{13} \mathrm{C}$ values most likely represent changes in local productivity often related with seasonal variations in freshwater and nutrient supplies (Figures 1 and 2). In contrast, ${ }^{14} \mathrm{C}$ ages do not change significantly with location, and all measured bivalves (Abra spp. and Nucula spp.) are the same age within the $\pm 1 \sigma$ level of uncertainty (Figures $3 b$ and $3 c$; Tables 4 and 5).

\section{Inter-Species Variability: Different Species-Same Location}

To discuss inter-species variability, in Shetland, we measured stable isotopes and ${ }^{14} \mathrm{C}$ ages in the shells of $A$. nitida (mixed feeder) and T. ovata (suspension feeder) (Table 6). Inter-species variability is significant in $\delta^{13} \mathrm{C}$ and $\delta^{18} \mathrm{O}$ measurements (Figure 2), whereas it does not affect ${ }^{14} \mathrm{C}$ ages, as the two species of bivalves are the same age within the $\pm 1 \sigma$ level of uncertainty (Figure $3 d$; Table 6 ).

[Insert Table 6 about here.]

In Forth, we measured stable isotopes and ${ }^{14} \mathrm{C}$ ages in the shells of $A$. alba (mixed feeder), C. gallina (suspension feeder) and $N$. turgida (deposit feeder) (Table 6). Considering all three species together, inter-species variability is significant in $\delta^{13} \mathrm{C}$ and $\delta^{18} \mathrm{O}$ measurements (Figure 2), whereas it does not affect ${ }^{14} \mathrm{C}$ ages, as all samples are the same age within the $\pm 1 \sigma$ level of uncertainty (Figure $3 \mathrm{~d}$; Table 6).

In Minch, we measured stable isotopes and ${ }^{14} \mathrm{C}$ in the shells of $A$. alba (mixed feeder), $T$. flexuosa (suspension feeder with chemosynthetic symbiont) and $N$. nucleus (deposit feeder) (Table 6). Considering all three species together, inter-species variability is significant in $\delta^{13} \mathrm{C}$ and $\delta^{18} \mathrm{O}$ measurements (Figure 2), whereas it does not affect ${ }^{14} \mathrm{C}$ ages, and all samples are the same age within the $\pm 1 \sigma$ level of uncertainty (Figure $3 d$; Table 6 ).

In Faroes, we measured stable isotopes and ${ }^{14} \mathrm{C}$ in the shells of Astarte borealis (suspension feeder), Astarte elliptica (suspension feeder) and N. nucleus (deposit feeder) (Table 6). In this particular case, combining data from all three species, inter-species variability is significant for both stable and radiogenic isotopes (Figures 2 and 3d; Table 6).

In summary, stable isotopes in marine bivalve shells can be reliably used to identify feeding strategies and ecological settings (Figure 2). Only A. elliptica falls outside the corresponding "feeding box" (Figure 2; black square in triangles group), perhaps suggesting a problem with the measurements performed in this shell or its identification. In contrast, ${ }^{14} \mathrm{C}$ ages show no evidence of sensitivity to mollusk diets or microhabitats, as all analyzed shells are the same age within the $\pm 1 \sigma$ level of uncertainty (Figure 
3d; Table 6). This includes the measurements from Faroes that locally showed significant interspecies variability (Table 6 ). Nevertheless, we acknowledge that with higher precision dates $( \pm 1 \sigma<35 \mathrm{yr}$ ) the difference in ${ }^{14} \mathrm{C}$ ages between specimens with different ecologies and feeding strategies might become significant.

\section{Does Diet Affect Radiocarbon Ages?}

Previously published ${ }^{14} \mathrm{C}$ ages, based on several species of mollusks and covering a range of environments, showed significant age differences between contemporaneous specimens (e.g. Forman and Polyak 1997; Hogg et al. 1998; Mangeroud et al. 2006; England et al. 2013; Petchey et al. 2013; Hadden and Cherkinsky 2017a; Rick et al. 2012; Rick and Henkes 2014). In these studies, older than expected ${ }^{14} \mathrm{C}$ ages were consistently measured in deposit feeding mollusks, as these species were argued to be able to incorporate old carbon in their shells. This apparent 'aging effect' can be due to two sources of "old" carbon: inorganic carbon from old calcareous sediments and/or terrestrial inputs (Forman and Polyak 1997; England et al. 2013), and old organic matter (yedoma) from the underlying sediments in samples coming from arctic regions (Forman and Polyak 1997; Guillemette et al. 2017). The latter source of old carbon could potentially explain the older ${ }^{14} \mathrm{C}$ ages reported in Mangeroud et al. (2006) and England et al. (2013) as their samples come from Svalbard, the Barents Sea and the Arctic Ocean. Additionally, high variability in ${ }^{14} \mathrm{C}$ ages within and between shells was found in samples collected in estuarine and brackish environments due to the mixing of marine and ${ }^{14} \mathrm{C}$-depleted fresh waters and to carbon recycling (Hadden and Cherkinsky 2017a; Rick et al. 2012; Rick and Henkes 2014). As a consequence, several researchers have suggested to either (i) exclude deposit feeders from palaeoenvironmental reconstructions, (ii) recommended species-specific correction factors to calibrate ${ }^{14} \mathrm{C}$ ages measured in deposit feeders, or (iii) advocated for the calculation of regional and sub-regional reservoir ages (Forman and Polyak 1997;Petchey et al. 2013; Hadden and Cherkinsky 2017a; Rick et al. 2012; England et al. 2013; Rick and Henkes 2014).

In this study, we combine stable isotopes and ${ }^{14} \mathrm{C}$ measurements for a range of marine bivalves having different feeding strategies and inhabiting a variety of ecological niches in the NE Atlantic. By pairing stable isotopes and ${ }^{14} \mathrm{C}$ measurements, we were able to better understand the mollusks' ecology (Figure 2) and thus better assess the reliability of ${ }^{14} \mathrm{C}$ ages (Figure 3). In situ variations of shell $\delta^{13} \mathrm{C}$ may reflect changes in carbon source, namely whether a mollusk is feeding on marine or terrestrial organic matter or switching between feeding strategies (Figure 2). Spatial changes in shell $\delta^{13} \mathrm{C}$ may indicate seasonal variations in marine productivity often related to freshwater input in fjordic and coastal systems (Figures 1 and 2). Similarly, in situ variations of $\delta^{18} O$ values can be due to differences in microhabitats and/or in shells time-average due to possibly different ontogenetic ages of the analyzed specimens (Figure 2), whereas spatial changes in $\delta^{18} \mathrm{O}$ may relate to seasonal changes in seawater temperature and salinity (Figures 1 and 2). In contrast, no statistically significant variation in ${ }^{14} \mathrm{C}$ measurements has been recorded in the compiled dataset (Figure $3 \mathrm{~d}$ ) and we would argue that all studied species can be used to provide a robust ${ }^{14} \mathrm{C}$ chronology independently of their diet. We speculate that, given the oceanography and geology of these sites in the NE Atlantic, seawater dissolved inorganic carbon is fairly homogeneous and unaffected by "old" carbon derived from the weathering of older rocks, ultimately resulting in the robust ${ }^{14} \mathrm{C}$ ages we measured (Figure 3). As already proposed by Petchey et al. (2013), pairing stable isotopes and ${ }^{14} \mathrm{C}$ ages provides an opportunity 
for a deeper understanding of environmental influences on ${ }^{14} \mathrm{C}$ dates, ultimately enabling an improved resolution of ${ }^{14} \mathrm{C}$ based chronologies.

\section{CONCLUSIONS}

The main conclusion that can be drawn from these results is that marine bivalve shells from the NE Atlantic can be used not only as reliable proxies for environmental and ecological change, but also for dating such reconstructions. As previously described in the literature, stable isotopes record changes in local environment, circulation (water mass) and ecology, being useful sources of palaeoarchives in coastal and continental shelf waters. Additionally, our results highlight that, in the NE Atlantic, mollusk carbonate provides a reliable basis for building the chronology of marine environmental change through ${ }^{14} \mathrm{C}$ dating, independently of vital effects and differences in microhabitats, feeding strategies and sample location. Reliable ${ }^{14} \mathrm{C}$ dating may still be compromised by the unknown incorporation of "old" carbon in mollusk shells in regions with "old" limestones. We therefore recommend the routine pairing of ${ }^{14} \mathrm{C}$ and stable isotopes $\left(\delta^{13} \mathrm{C}\right.$ and $\left.\delta^{18} \mathrm{O}\right)$ measurements to provide an improved ecological context for interpreting ${ }^{14} \mathrm{C}$ ages.

\section{ACKNOWLEDGMENTS}

We acknowledge the support of NERC and an award to WA through the RAPID program (project $\mathrm{NE} / \mathrm{C} 000137 / 1$ ) and we thank the National Museum of Scotland for making the shell material available to us. Many of these analyses were conducted with the support of Louise Brown at the University of St Andrews, working alongside colleagues at SUERC, East Kilbride-notably Steve Moreton and Charlotte Bryant; we thank all these colleagues for their help. We thank two anonymous reviewers and the Associate Editor Dr Quan Hua for valuable and constructive comments that improved the manuscript. We acknowledge the support of the University of St Andrews in providing laboratory facilities for this research. 
Table 1 Shells species, ecologies, and habitats. ${ }^{*}$

\begin{tabular}{|c|c|c|c|}
\hline Species & Feeding strategy & Substrate & Depth habitat \\
\hline Abra alba & Mixed feeder & $\begin{array}{l}\text { Muds, silty sands and } \\
\text { soft muddy gravel }\end{array}$ & $\begin{array}{l}\text { From extreme low } \\
\text { watermark to about } 65 \mathrm{~m} \\
\text { water depth }\end{array}$ \\
\hline Abra nitida & Mixed feeder & $\begin{array}{l}\text { Muds, sandy muds, silty } \\
\text { sands and muddy gravel }\end{array}$ & $\begin{array}{l}\text { Offshore to depths of about } \\
180 \mathrm{~m}\end{array}$ \\
\hline Astarte borealis & Suspension feeders & Sandy muds and gravel & Below 5 m water depth \\
\hline Astarte elliptica & Suspension feeders & Sandy muds and gravel & Below 5 m water depth \\
\hline Chamelea gallina & Suspension feeder & $\begin{array}{l}\text { Clean sands and muddy } \\
\text { sands-infaunal } \\
\text { burrower }\end{array}$ & $\begin{array}{l}\text { Above the low watermark } \\
\text { to about } 50 \mathrm{~m} \text { water depth }\end{array}$ \\
\hline Nucula nucleus & Deposit feeder & Coarse sediments & $\begin{array}{l}\text { To about } 140 \mathrm{~m} \text { water } \\
\text { depth }\end{array}$ \\
\hline Nucula turgida & Deposit feeder & $\begin{array}{l}\text { Fine sediments- } \\
\text { infaunal }\end{array}$ & To 90 m water depth \\
\hline Thyasira flexuosa & $\begin{array}{l}\text { Symbiont barer and } \\
\text { suspension feeder }\end{array}$ & Sandy muds & $\begin{array}{l}\text { From } 10 \text { to } 180 \mathrm{~m} \text { water } \\
\text { depth }\end{array}$ \\
\hline Timoclea ovata & Suspension feeder & $\begin{array}{l}\text { Sands, muddy sands, } \\
\text { shell gravel and gravel- } \\
\text { shallow burrower }\end{array}$ & $\begin{array}{l}\text { From } 4 \text { to } 180 \mathrm{~m} \text { water } \\
\text { depth }\end{array}$ \\
\hline
\end{tabular}

*Ecology and habitat information is from Tebble (1966). 
Table 2 Sample list.*

\begin{tabular}{|c|c|c|c|c|c|c|}
\hline $\begin{array}{l}\text { Lab } \\
\text { Identifier }\end{array}$ & $\begin{array}{l}\text { AMS publication } \\
\text { code }\end{array}$ & Location & Latitude (N) & Longitude (W) & Species & $\begin{array}{l}\text { Feeding } \\
\text { strategy }\end{array}$ \\
\hline GR/7903 & SUERC-11180 & Shetland & 60.2 & 1.51 & SA1-Abra nitida $(a)^{* *}$ & Mixed \\
\hline GR/7904 & SUERC-11181 & Shetland & 60.2 & 1.51 & SA1-Abra nitida $(b)^{* *}$ & Mixed \\
\hline GR/7905 & SUERC-11182 & Shetland & 60.2 & 1.51 & SA1-Abra nitida (c) ${ }^{* *}$ & Mixed \\
\hline GR/7906 & SUERC-11183 & Shetland & 60.2 & 1.51 & SA1-Timoclea ovata & Suspension \\
\hline GR/7907 & SUERC-11184 & Cromarty & 57.47 & 4.09 & SA5-Abra nitida & Mixed \\
\hline GR/7908 & SUERC-11185 & Forth & 56.15 & 2.53 & SA7-Chamelia gallina $(a)^{* *}$ & Suspension \\
\hline GR/7909 & SUERC-11186 & Forth & 56.15 & 2.53 & SA7-Chamelia gallina $(b)^{* *}$ & Suspension \\
\hline GR/7910 & SUERC-11189 & Forth & 56.15 & 2.53 & SA7-Abra alba (a)** & Mixed \\
\hline GR/7911 & SUERC-11191 & Forth & 56.15 & 2.53 & SA7-Abra alba (b)** & Mixed \\
\hline $\mathrm{GR} / 7912 \mathrm{R}$ & SUERC-11192 & Forth & 56.15 & 2.53 & SA7-Abra alba (c) & Mixed \\
\hline GR/7913 & SUERC-11193 & Forth & 56.15 & 2.53 & SA7-Nucula turgida $(a)^{* *}$ & Deposit \\
\hline GR/7914 & SUERC-11195 & Forth & 56.15 & 2.53 & SA7-Nucula turgida $(b)^{* *}$ & Deposit \\
\hline GR/7915 & SUERC-11196 & Minch & 58.18 & 6.13 & SA30-Abra alba $(a)^{* *}$ & Mixed \\
\hline GR/7916 & SUERC-11199 & Minch & 58.18 & 6.13 & SA30-Abra alba (b)** & Mixed \\
\hline GR/7917 & SUERC-11200 & Minch & 58.18 & 6.13 & SA30-Thyasira flexuosa $(a)^{* *}$ & Suspension \\
\hline GR/7918 & SUERC-11201 & Minch & 58.18 & 6.13 & SA30-Thyasira flexuosa $(b)^{* *}$ & Suspension \\
\hline GR/7919 & SUERC-11203 & Minch & 58.06 & 6.29 & SA30-Nucula nucleus & Deposit \\
\hline GR/7920 & SUERC-11204 & Hebrides & 58.12 & 6.46 & SA31-Abra nitida & Mixed \\
\hline GR/7921 & SUERC-11205 & Hebrides & 58.12 & 6.46 & SA31-Abra alba & Mixed \\
\hline GR/7922 & SUERC-11206 & Faeroes & 62.2 & 6.29 & SA48-Astarte borealis & Suspension \\
\hline GR/7923 & SUERC-11209 & Faeroes & 62.2 & 6.29 & SA48-Astarte elliptica & Suspension \\
\hline GR/7924 & SUERC-11210 & Faeroes & 62.2 & 6.29 & SA48-Nucula nucleus $(a)^{* *}$ & Deposit \\
\hline GR/7925 & - & Faeroes & 62.2 & 6.29 & SA48-Nucula nucleus $(b)^{* *}$ & Deposit \\
\hline
\end{tabular}

* All samples come from coastal waters. Feeding strategies are largely based on the interpretations of Tebble (1966).

**Replicate analyses. Please note that replicates (a), (b), and (c) refer to individual samples, not repeat measurements on the same shell. 
Table 3 In situ variability.*

\begin{tabular}{|c|c|c|c|c|c|c|c|}
\hline Lab Identifier & $\begin{array}{l}\text { AMS publication } \\
\text { code }\end{array}$ & Locality & Species & Feeding & ${ }^{14} \mathrm{C}$ age $\mathrm{BP}$ & $\begin{array}{l}1 \sigma \quad{ }^{14} \mathrm{C} \text { age } \\
\text { error }\end{array}$ & $\begin{array}{l}\text { Year of } \\
\text { Collection }\end{array}$ \\
\hline GR/7903 & SUERC-11180 & Shetland & SA1-Abra nitida (a) & Mixed & 498 & 37 & 1924 \\
\hline GR/7904 & SUERC-11181 & Shetland & SA1-Abra nitida (b) & Mixed & 510 & 35 & 1924 \\
\hline \multirow[t]{4}{*}{ GR/7905 } & SUERC-11182 & Shetland & SA1-Abra nitida (c) & Mixed & 467 & 35 & 1924 \\
\hline & & & & & $A_{p}=491$ & & \\
\hline & & & & & $\mathrm{T}=\mathbf{0 . 8}$ & & \\
\hline & & & & & $\chi^{2} .05=6$ & & \\
\hline GR/7908 & SUERC-11185 & Forth & SA7-Chamelia gallina (a) & Suspension & 464 & 35 & 1925 \\
\hline \multirow[t]{4}{*}{ GR/7909 } & SUERC-11186 & Forth & SA7-Chamelia gallina (b) & Suspension & 417 & 35 & 1925 \\
\hline & & & & & $A_{p}=441$ & & \\
\hline & & & 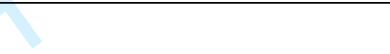 & & $\mathrm{T}=0.9$ & & \\
\hline & & & 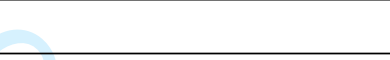 & & $\chi^{2} .05=3.8$ & & \\
\hline GR/7910 & SUERC-11189 & Forth & SA7-Abra alba (a) & Mixed & 517 & 35 & 1924 \\
\hline GR/7911 & SUERC-11191 & Forth & SA7-Abra alba (b) & Mixed & 496 & 35 & 1924 \\
\hline \multirow[t]{4}{*}{ GR/7912R } & SUERC-11192 & & SA7-Abra alba (c) & Mixed & 467 & 35 & 1924 \\
\hline & & & & & $A_{p}=493$ & & \\
\hline & & & & & $T=1.0$ & & \\
\hline & & & & & $\chi^{2} .05=6$ & & \\
\hline GR/7913 & SUERC-11193 & Forth & SA7-Nucula turgida (a) & Deposit & 462 & 35 & 1924 \\
\hline \multirow[t]{4}{*}{ GR/7914 } & SUERC-11195 & Forth & SA7-Nucula turgida (b) & Deposit & 447 & 35 & 1924 \\
\hline & & & & & $A_{p}=455$ & & \\
\hline & & & & & $T=0.1$ & & \\
\hline & & & & & $\chi^{2} .05=3.8$ & & \\
\hline GR/7915 & SUERC-11196 & Minch & SA30- Abra alba (a) & Mixed & 552 & 35 & 1924 \\
\hline \multirow[t]{4}{*}{ GR/7916 } & SUERC-11199 & Minch & SA30- Abra alba (b) & Mixed & 448 & 35 & 1924 \\
\hline & & & & & $A_{p}=\mathbf{5 0 0}$ & & \\
\hline & & & & 8 & $T=4.4$ & & \\
\hline & & & & & $\chi^{2} .05=3.8$ & & \\
\hline GR/7917 & SUERC-11200 & Minch & SA30-Thyasira flexuosa (a) & Symbiont & 532 & 35 & 1924 \\
\hline \multirow[t]{4}{*}{ GR/7918 } & SUERC-11201 & Minch & SA30-Thyasira flexuosa (b) & Symbiont & 506 & 39 & 1924 \\
\hline & & & & & $A_{p}=520$ & & \\
\hline & & & & & $\mathrm{T}=0.2$ & & \\
\hline & & & & & $\chi^{2} .05=3.8$ & & \\
\hline
\end{tabular}

*Red numbers indicate when in situ variability is statistically significant for $\alpha=0.05$. (Please see electronic version for color.) 
Table 4 Abra spp. (mixed feeder) inter-locality variability.

\begin{tabular}{|l|l|l|l|l|l|}
\hline Lab Identifier & $\begin{array}{l}\text { AMS publication } \\
\text { code }\end{array}$ & Locality & Species & ${ }^{14}$ C age BP & $1 \sigma^{14}$ C age error \\
\hline GR/7903 & SUERC-11180 & Shetland & SA1-Abra nitida (a) & 498 & 37 \\
\hline GR/7904 & SUERC-11181 & Shetland & SA1-Abra nitida (b) & 510 & 35 \\
\hline GR/7905 & SUERC-11182 & Shetland & SA1-Abra nitida (c) & 467 & 35 \\
\hline GR/7907 & SUERC-11184 & Cromarty & SA5-Abra nitida & 475 & 35 \\
\hline GR/7910 & SUERC-11189 & Forth & SA7-Abra alba (a) & 517 & 35 \\
\hline GR/7911 & SUERC-11191 & Forth & SA7-Abra alba (b) & 496 & 35 \\
\hline GR/7912R & SUERC-11192 & Forth & SA7-Abra alba (c) & 467 & 35 \\
\hline GR/7915 & SUERC-11196 & Minch & SA30- Abra alba (a) & 552 & 35 \\
\hline GR/7916 & SUERC-11199 & Minch & SA30-Abra alba (b) & 448 & 35 \\
\hline GR/7920 & SUERC-11204 & Hebrides & SA31-Abra nitida & 476 & 35 \\
\hline GR/7921 & SUERC-11205 & Hebrides & SA31-Abra alba & 477 & 35 \\
\hline & & & & $\mathbf{A}_{\mathbf{p}}=\mathbf{4 8 9}$ & \\
\hline & & & & $\mathbf{T}=\mathbf{6 . 9}$ & \\
\hline & & & & $\chi^{2} .05=18.3$ & \\
\hline
\end{tabular}

Table 5 Nucula spp. (deposit feeder) inter-locality variability.

\begin{tabular}{|l|l|l|l|l|l|}
\hline Lab Identifier & $\begin{array}{l}\text { AMS publication } \\
\text { Code }\end{array}$ & Locality & Species & ${ }^{14}$ C age BP & $1 \sigma^{14}$ C age error \\
\hline GR/7913R & SUERC-11193 & Forth & SA7- Nucula turgida (a) & 462 & 35 \\
\hline GR/7914 & SUERC-11195 & Forth & SA7- Nucula turgida (b) & 447 & 35 \\
\hline GR/7919 & SUERC-11203 & Minch & SA30-Nucula nucleus & 452 & 35 \\
\hline GR/7924 & SUERC-11210 & Faroes & SA48-Nucula nucleus (a) & 554 & 35 \\
\hline & & & & $\mathbf{A}_{\mathrm{p}}=\mathbf{4 7 9}$ & \\
\hline & & & & $\mathbf{T}=\mathbf{6 . 2}$ & \\
\hline & & & & $\chi^{\mathbf{2} .05}=\mathbf{7 . 8}$ & \\
\hline
\end{tabular}


Table 6 Inter-species variability. ${ }^{*}$

\begin{tabular}{|c|c|c|c|c|c|}
\hline Lab Identifier & AMS publication code & Locality & Species & ${ }^{14} \mathrm{C}$ age $\mathrm{BP}$ & $1 \sigma^{14} \mathrm{C}$ age error \\
\hline GR/7903 & SUERC-11180 & Shetland & SA1-Abra nitida (a) & 498 & 37 \\
\hline GR/7904 & SUERC-11181 & Shetland & SA1-Abra nitida (b) & 510 & 35 \\
\hline GR/7905 & SUERC-11182 & Shetland & SA1-Abra nitida (c) & 467 & 35 \\
\hline \multirow[t]{4}{*}{ GR/7906 } & SUERC-11183 & Shetland & SA1-Timoclea ovata & 507 & 35 \\
\hline & & & & $A_{p}=495$ & \\
\hline & & & & $T=0.9$ & \\
\hline & & & & $\chi^{2} .05=7.8$ & \\
\hline GR/7908 & SUERC-11185 & Forth & SA7-Chamelia gallina (a) & 464 & 35 \\
\hline GR/7909A & SUERC-11186 & Forth & SA7-Chamelia gallina (b) & 417 & 35 \\
\hline GR/7910 & SUERC-11189 & Forth & SA7-Abra alba (a) & 517 & 35 \\
\hline GR/7911 & SUERC-11191 & Forth & SA7-Abra alba (b) & 496 & 35 \\
\hline GR/7912R & SUERC-11192 & Forth & SA7-Abra alba (c) & 467 & 35 \\
\hline GR/7913R & SUERC-11193 & Forth & SA7- Nucula turgida (a) & 462 & 35 \\
\hline \multirow[t]{4}{*}{ GR/7914 } & SUERC-11195 & Forth & SA7- Nucula turgida (b) & 447 & 35 \\
\hline & & & & $A_{p}=467$ & \\
\hline & 20 & & & $\mathrm{~T}=5.1$ & \\
\hline & 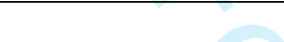 & & & $\chi^{2} .05=12.6$ & \\
\hline GR/7915 & SUERC-11196 & Minch & SA30- Abra alba (a) & 552 & 35 \\
\hline GR/7916 & SUERC-11199 & Minch & SA30-Abra alba (b) & 448 & 35 \\
\hline GR/7917 & SUERC-11200 & Minch & SA30-Thyasira flexuosa (a) & 532 & 35 \\
\hline GR/7918 & SUERC-11201 & Minch & SA30-Thyasira flexuosa (b) & 506 & 39 \\
\hline \multirow[t]{4}{*}{ GR/7919 } & SUERC-11203 & Minch & SA30-Nucula nucleus & 452 & 35 \\
\hline & & 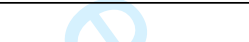 & & $A_{p}=498$ & \\
\hline & & 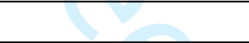 & & $T=7.1$ & \\
\hline & & +1 & & $\chi^{2} .05=9.5$ & \\
\hline GR/7920 & SUERC-11204 & Hebrides & SA31-Abra nitida & 476 & 35 \\
\hline \multirow[t]{4}{*}{ GR/7921 } & SUERC-11205 & Hebrides & SA31-Abra alba & 477 & 35 \\
\hline & & & ( & $A_{p}=477$ & \\
\hline & & & 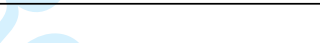 & $T=0.0$ & \\
\hline & & & $4=$ & $\chi_{.05}^{2}=3.8$ & \\
\hline GR/7922 & SUERC-11206 & Faroes & SA48-Astarte borealis & 414 & 35 \\
\hline GR/7923 & SUERC-11209 & Faroes & SA48-Tridonta elliptica & 540 & 35 \\
\hline \multirow[t]{4}{*}{ GR/7924 } & SUERC-11210 & Faroes & SA48-Nucula nucleus (a) & 554 & 35 \\
\hline & & & 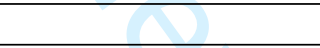 & $A_{p}=503$ & \\
\hline & & & +2 & $\mathrm{~T}=9.7$ & \\
\hline & & & 8 & $\chi^{2} .05=6$ & \\
\hline \multirow[t]{5}{*}{ GR/7907 } & SUERC-11184 & Cromarty & SA5-Abra nitida & 475 & 35 \\
\hline & & & All shells together & $A_{p}=485$ & \\
\hline & & & & $\mathrm{T}=\mathbf{2 6 . 7}$ & \\
\hline & & & & $\chi^{2} .05=32.7$ & \\
\hline & & & & & \\
\hline
\end{tabular}

*Red numbers indicate when inter species variability is statistically significant for $\alpha=0.05$. 


\section{REFERENCES}

Ascough PL, Cook GT, Dugmore AJ, Scott EM, Freeman SPHT. 2005. Influence of mollusk species on marine $\Delta R$ determinations. Radiocarbon 47(3):433-440.

Austin WEN, Hibbert FD, Rasmussen SO, Peters C, Abbott PM, Bryant CL. 2012. The synchronization of palaeoclimatic events in the North Atlantic region during Greenland Stadial 3 (ca 27.5 to 23.3kyr b2k). Quaternary Science Reviews 36:154-163.

Balasse M, Tresset A, Dobney K, Ambrose SH. 2005. The use of isotope ratios to test for seaweed eating in sheep. Journal of Zoology 266(3):283-291.

Batenburg SJ, Reichart GJ, Jilbert T, Janse M, Wesselingh FP, Renema W. 2011. Interannual climate variability in the Miocene: high resolution trace element and stable isotope ratios in giant clams. Palaeogeography, Palaeoclimatology, Palaeoecology 306(1-2):75-81.

Baxter JM, Boyd IL, Cox M, Donald AE, Malcolm SJ, Miles H, Miller B, Moffat CF, editors. 2011. Scotland's Marine Atlas: information for the national marine plan. Edinburgh: Marine Scotland. p. 191.

Berkman PA, Forman SL. 1996. Pre-bomb radiocarbon and the reservoir correction for calcareous marine species in the Southern Ocean. Geophysical Research Letters 23(4):363-366.

Cage AG, Heinemeier J, Austin WEN. 2006. Marine radiocarbon reservoir ages in Scottish coastal and fjordic waters. Radiocarbon 48(1):31-43.

Cefas. 2010a. Scottish Sanitary Survey Project Sanitary Survey Report Cromarty Shoremill / Cromarty Bay Mussels Report Distribution - Cromarty (March).

Cefas. 2010b. Scottish Sanitary Survey Project Sanitary Survey Report Loch Erisort : Outer February 2010 Report Distribution - Loch Erisort : Outer (February).

Cefas. 2010c. Scottish Sanitary Survey Project Sanitary Survey Report Report Distribution - Lower Gruting Voe (February).

Cefas. 2011. Scottish Sanitary Survey Project Sanitary Survey Report Loch Leurbost and Loch Leurbost : Crosbost March 2011 Report Distribution - Loch Leurbost and Loch Leurbost : Crosbost (March).

Cefas. 2013. Sanitary Survey Report Forth Estuary : Anstruther (March).

Dame RF. 1996. Ecology of marine bivalves; an ecosystem approach. CRC Marine Science Series. doi:10.1201/9781420049787

DeNiro MJ, Epstein S. 1978. Influence of diet on the distribution of carbon isotopes in animals. Geochimica et Cosmochimica Acta:495-506.

Eiríksson J, Larsen G, Knudsen KL, Heinemeier J, Símonarson LA. 2004. Marine reservoir age variability and water mass distribution in the Iceland Sea. Quaternary Science Reviews 23(20-22 SPEC. ISS.):2247-2268.

England J, Dyke AS, Coulthard RD, Mcneely R, Aitken A. 2013. The exaggerated radiocarbon age of deposit-feeding molluscs in calcareous environments. Boreas 42(2):362-373. 
Ficken KJ, Barber KE, Eglinton G. 1998. Lipid biomarker, $\delta^{13} \mathrm{C}$ and plant macrofossil stratigraphy of a Scottish montane peat bog over the last two millennia. Organic Geochemistry 28(3-4):217-237.

Forman S. L, Polyak L. 1997. Radiocarbon content of pre-bomb marine mollusks and variations in the ${ }^{14} \mathrm{C}$ reservoir age for coastal areas of the Barents and Kara seas, Russia. Geophysical Research Letters 24(8):885-888.

Gillespie RG, Clague DA. 2009. Encyclopedia of islands. 1st edition. University of California Press.

Gillikin DP, Lorrain A, Bouillon S, Willenz P, Dehairs F. 2006. Stable carbon isotopic composition of Mytilus edulis shells: relation to metabolism, salinity, $\delta^{13} C_{D I C}$ and phytoplankton. Organic Geochemistry 37(10):1371-1382.

Guillemette F, Bianchi TS, Spencer RGM. 2017. Old before your time: Ancient carbon incorporation in contemporary aquatic foodwebs. Limnology and Oceanography 62(4):1682-1700.

Hadden CS, Cherkinsky A. 2015. ${ }^{14} \mathrm{C}$ Variations in pre-bomb nearshore habitats of the Florida Panhandle, USA. Radiocarbon 57(3):469-479.

doi:10.2458/azu_rc.57.18353

Hadden CS, Cherkinsky A. 2017a. Carbon reservoir effects in eastern oyster from Apalachicola Bay, USA. Radiocarbon 59(05):1497-1506.

Hadden CS, Cherkinsky A. 2017b. Spatiotemporal variability in $\triangle R$ in the northern Gulf of Mexico, USA. Radiocarbon 59(2):343-353.

Harkness DD. 1983. The extent of natural ${ }^{14} \mathrm{C}$ deficiency in the coastal environment of the United Kingdom. In: Mook WG, Waterbolk HT, editors. Proceedings of the Symposium ${ }^{14} \mathrm{C}$ and Archaeology. PACT 8:351-379.

Hogg AG, Higham TFG, Dahm J. 1998. ${ }^{14} \mathrm{C}$ dating of modern marine and estuarine shellfish. Radiocarbon 40(2):975-984.

Inall M, Gillibrand P, Griffiths C, MacDougal N, Blackwell K. 2009. On the oceanographic variability of the North-West European Shelf to the west of Scotland. Journal of Marine Systems 77(3):210-226.

Jull AJT, Burr GS, Hodgins GWL. 2013. Radiocarbon dating, reservoir effects, and calibration. Quaternary International 299:64-71.

Mangerud J, Bondevik S, Gulliksen S, Karin Hufthammer A, Høisæter T. 2006. Marine ${ }^{14} \mathrm{C}$ reservoir ages for 19th century whales and molluscs from the North Atlantic. Quaternary Science Reviews 25(2324):3228-3245.

Marconi M, Giordano M, Raven JA. 2011. Impact of taxonomy, geography, and depth on $\delta^{13} \mathrm{C}$ and $\delta^{15} \mathrm{~N}$ Variation in a large collection of macroalgae. Journal of Phycology 47(5):1023-1035.

McConnaughey TA, Gillikin DP. 2008. Carbon isotopes in mollusk shell carbonates. Geo-Marine Letters 28(5-6):287-299.

Mettam C, Johnson ALA, Nunn EV, Schöne BR. 2014. Stable isotope $\left(\delta^{18} \mathrm{O}\right.$ and $\left.\delta^{13} \mathrm{C}\right)$ sclerochronology of Callovian (Middle Jurassic) bivalves (Gryphaea (Bilobissa) dilobotes) and belemnites 
(Cylindroteuthis puzosiana) from the Peterborough Member of the Oxford Clay Formation (Cambridgeshire, England): Eviden. Palaeogeography, Palaeoclimatology, Palaeoecology 399:187-201.

Petchey F, Ulm S, David B, McNiven IJ, Asmussen B, Tomkins H, Dolby N, Aplin K, Richards T, Rowe C, Leavesley M, Mandui H. 2013. High-resolution radiocarbon dating of marine materials in archaeological contexts: radiocarbon marine reservoir variability between Anadara, Gafrarium, Batissa, Polymesoda spp. and Echinoidea at Caution Bay, Southern Coastal Papua New Guinea. Archaeological and Anthropological Sciences 5(1):69-80.

Reich S, Warter V, Wesselingh FP, Zwaan J. C, Lourens L, Renema W. 2015. Paleoecological significance of stable isotope ratios in Miocene Tropical shallow marine habitats (Indonesia). Palaios 30(1):53-65.

Rick TC, Henkes GA. 2014. Radiocarbon variability in Crassostrea virginica shells from the Chesapeake Bay, USA. Radiocarbon 56(01):305-311.

Rick TC, Henkes GA, Lowery DL, Colman SM, Culleton BJ. 2012. Marine radiocarbon reservoir corrections $\Delta R$ for Chesapeake Bay and the Middle Atlantic Coast of North America. Quaternary Research 77(1):205-210.

Ruppert EE, Fox RS, Barnes RD. 2004. Invertebrate zoology: a functional evolutionary approach. Systematic Biology 53(4):662-664.

Schiener P, Black KD, Stanley MS, Green DH. 2014. The seasonal variation in the chemical composition of the kelp species Laminaria digitata, Laminaria hyperborea, Saccharina latissima and Alaria esculenta. Journal of Applied Phycology 27(1):363-373.

Schmidt MWI, Gleixner G. 2005. Carbon and nitrogen isotope composition of bulk soils, particle-size fractions and organic material after treatment with hydrofluoric acid. European Journal of Soil Science 56(3):407-416.

Seidov DOK, Baranova TP, Boyer SL, Cross AV, Mishonov AR, Parsons JR, Reagan KWW. 2018. Greenland-Iceland-Norwegian Seas Regional Climatology version 2. NOAA/NCEI.

Sharma T, Clayton RN. 1965. Measurement of 018016 ratios of total oxygen of carbonates. Geochimica et Cosmochimica Acta 29(12):1347-1353.

Simstich J, Erlenkeuser H, Harms I Spielhagen RF, Stanovoy V. 2005a. Modern and Holocene hydrographic characteristics of the shallow Kara Sea shelf (Siberia) as reflected by stable isotopes of bivalves and benthic foraminifera. Boreas 34(3):252-263.

Simstich J, Harms I, Karcher M. J, Erlenkeuser H, Stanovoy V, Kodina L, Bauch D, Spielhagen RF. 2005b. Recent freshening in the Kara Sea (Siberia) recorded by stable isotopes in Arctic bivalve shells. Journal of Geophysical Research C: Oceans 110(8):1-11.

Stephen AC. 1934. XXII.-Studies on the Scottish marine fauna: the natural faunistic divisions of the North Sea as shown by the quantitative distribution of the molluscs. Transactions of the Royal Society of Edinburgh 57(03):601-616.

Tanaka N, Monaghan MC, Rye DM. 1986. Contribution of metabolic carbon to mollusc and barnacle shell carbonate. Nature 320(6062):520-523. 
Tebble N. 1966. British bivalve seashells : a handbook for identification. London: British Museum (Natural History).

Tisnérat-Laborde N, Paterne M, Métivier B, Arnold M, Yiou P, Blamart D, Raynaud S. 2010. Variability of the northeast Atlantic sea surface $\Delta^{14} \mathrm{C}$ and marine reservoir age and the North Atlantic Oscillation (NAO). Quaternary Science Reviews 29(19-20):2633-2646.

Ward GK, Wilson SR. 1978. Procedures for comparing and combining radiocarbon age determinations: a critique. Archaeometry 20(1):19-31.

Warter V, Muller W, Wesselingh FP, Todd JA, Renema W. 2015. Late Miocene seasonal to subdecadal climate variability in the Indo-West Pacific (east Kalimantan, Indonesia) preserved in giant clams. Palaios 30(1):66-82.

Yoneda M, Kitagawa H, van der Plicht J, Uchida M, Tanaka A, Uehiro T, Shibata Y, Morita M, Ohno T. 2000. Pre-bomb marine reservoir ages in the western north Pacific: Preliminary result on Kyoto University collection. Nuclear Instruments and Methods in Physics Research Section B: Beam Interactions with Materials and Atoms 172(1-4):377-381.

Yonge M. 1939. The protobranchiate mollusca; a functional interpretation of their structure and evolution. Philosophical Transactions of the Royal Society of London. Series B, Biological Sciences 230(566):79-148. 


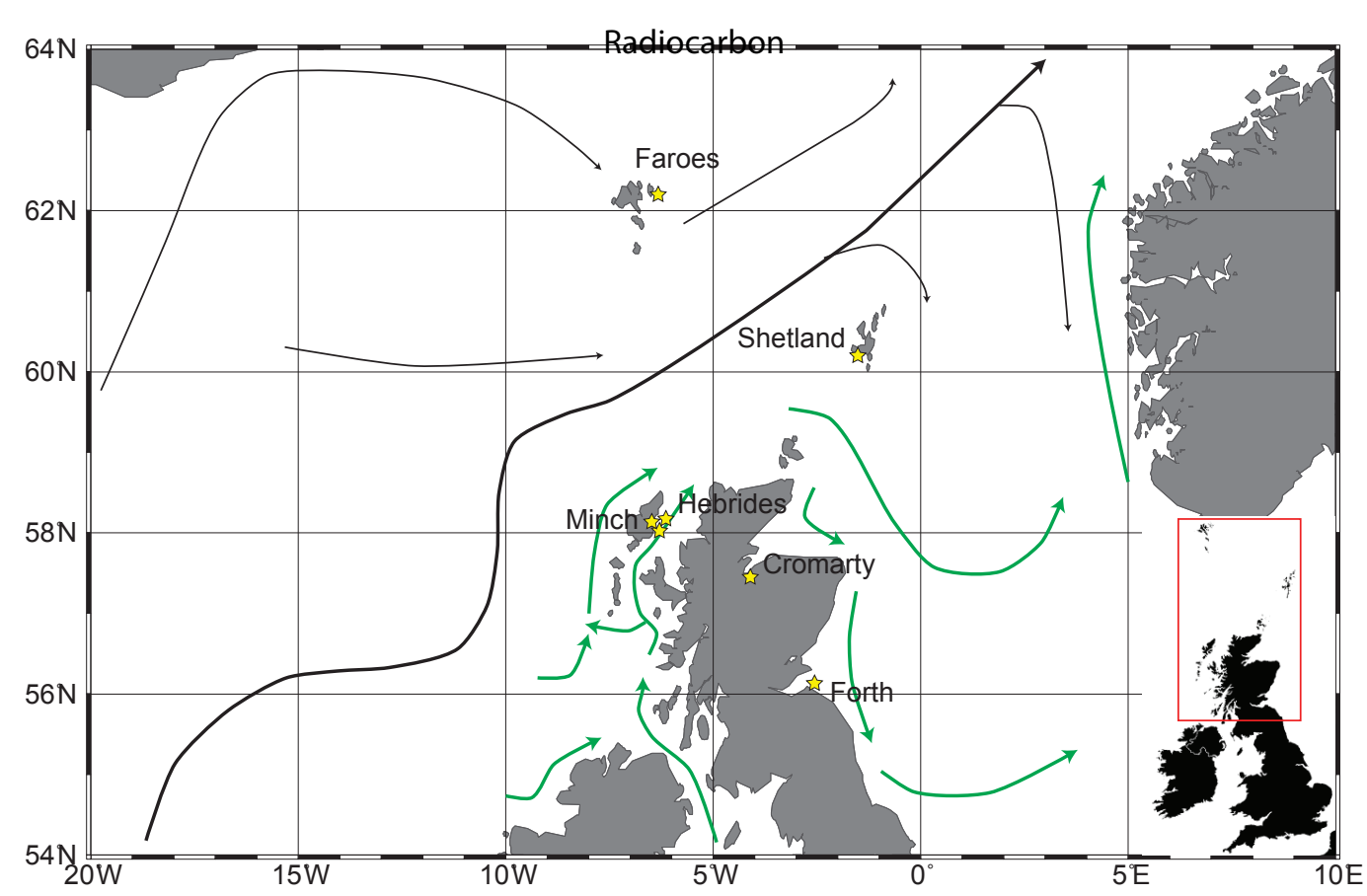

SSS (PSU)

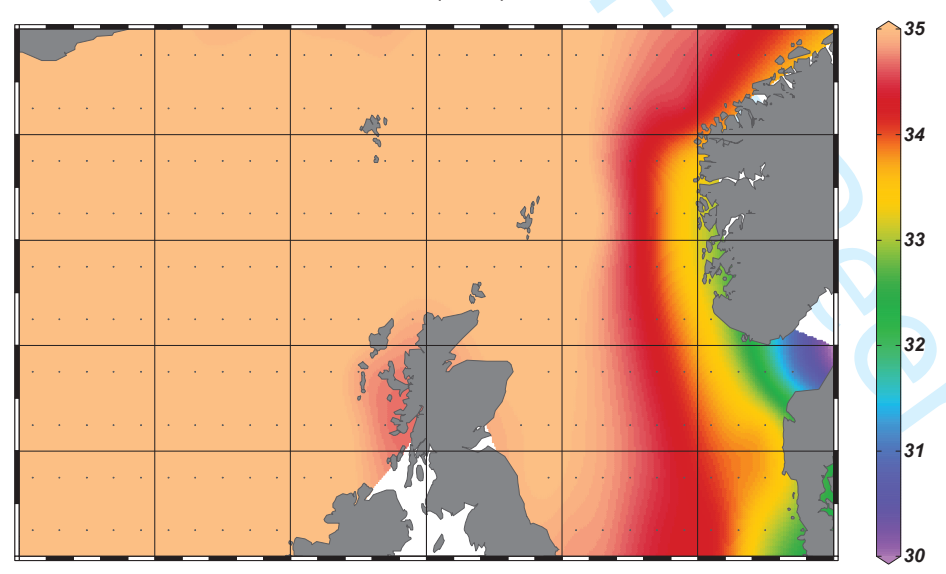

SST (C)

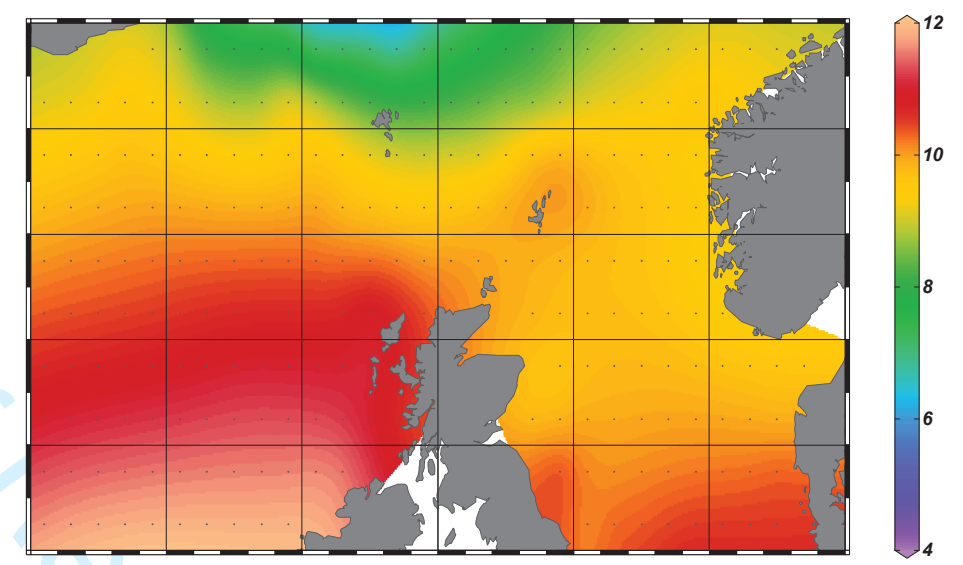




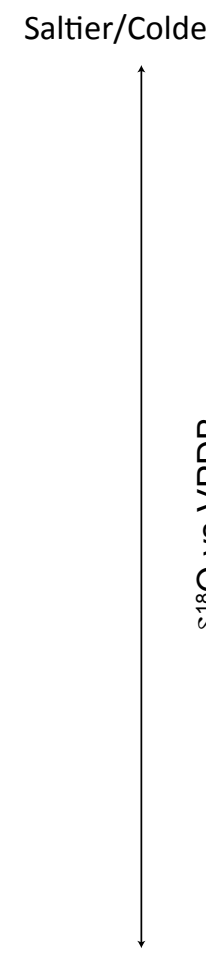

Fresher/Warmer

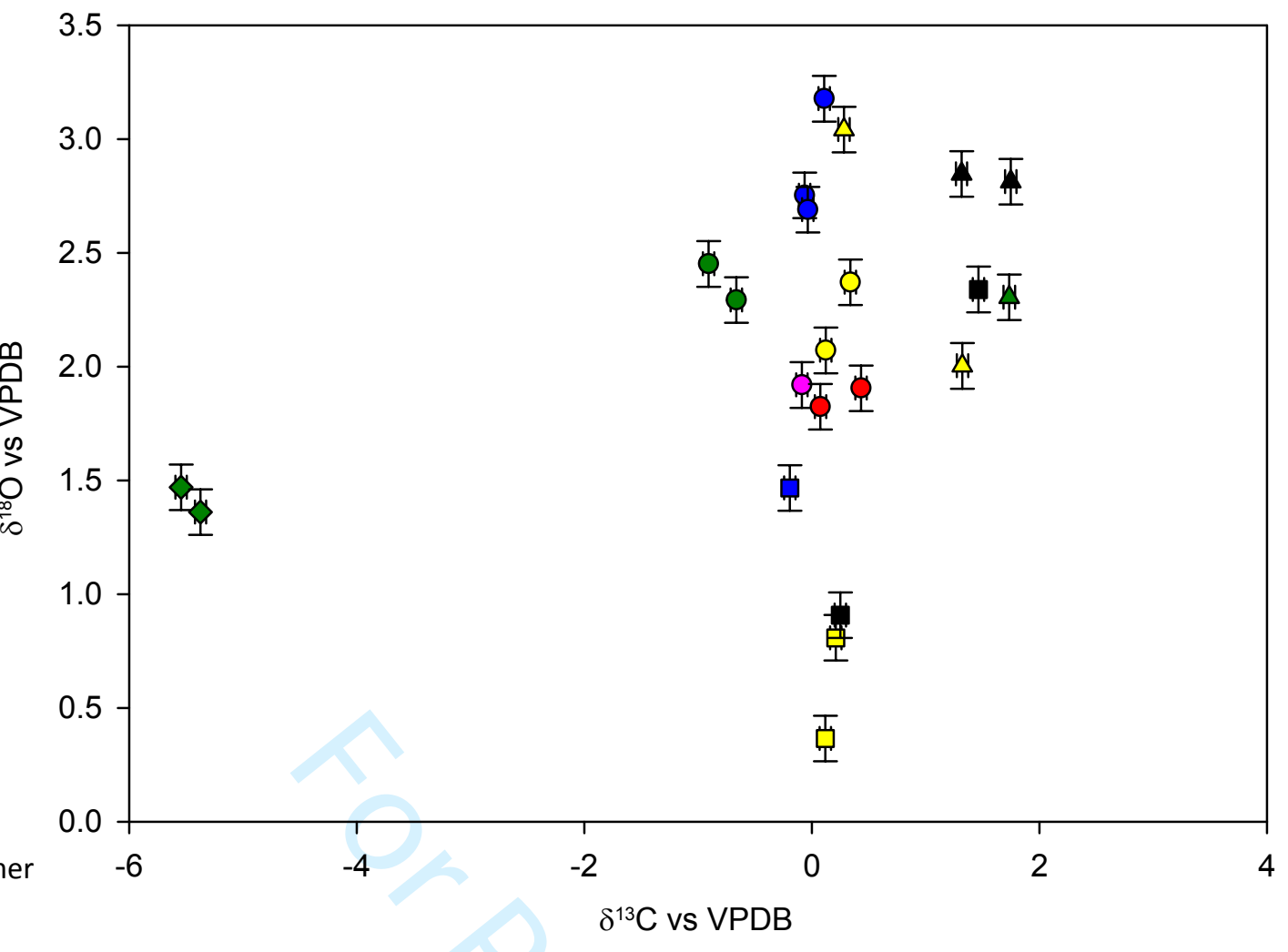

Terrestrial (low productivity)

Marine (high productivity)

\begin{tabular}{|c|c|c|}
\hline 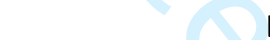 & & \\
\hline $\begin{array}{l}\text { Mixed feeders } \\
\text { Suspension feeders } \\
\text { Depositfeeders } \\
\text { Symbiont bearer }\end{array}$ & $\begin{array}{l}\text { Shetland } \\
\text { Cromarty } \\
\text { Forth } \\
\text { Minch }\end{array}$ & $\begin{array}{l}\text { Hebrides } \\
\text { Faroes }\end{array}$ \\
\hline
\end{tabular}


Page 21 af Zn] situ variability

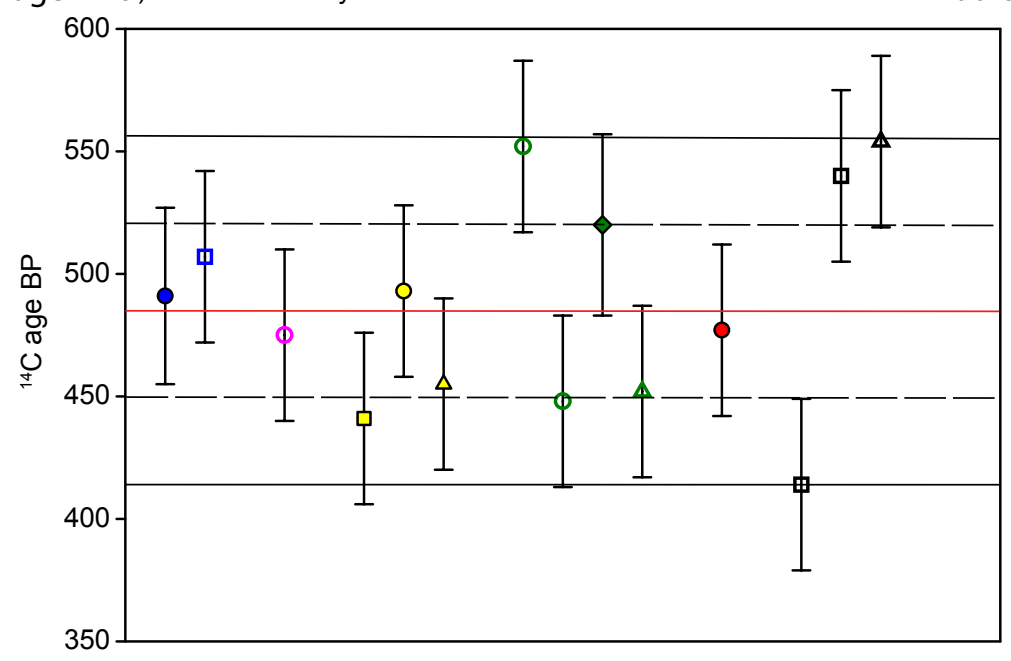

b) Intra species variability

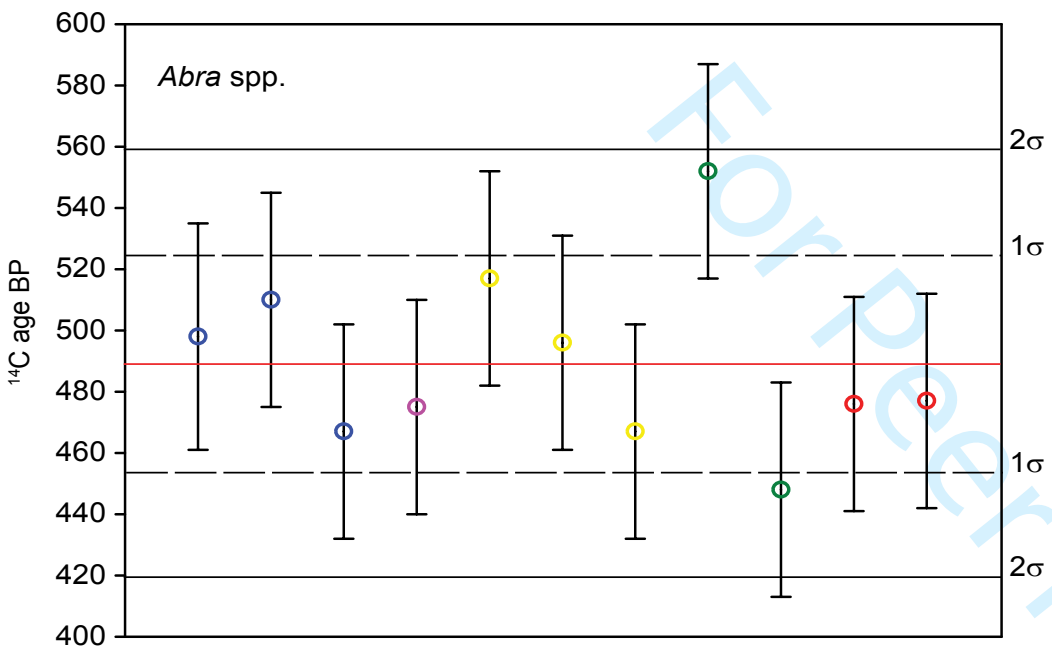

d) Inter species variability

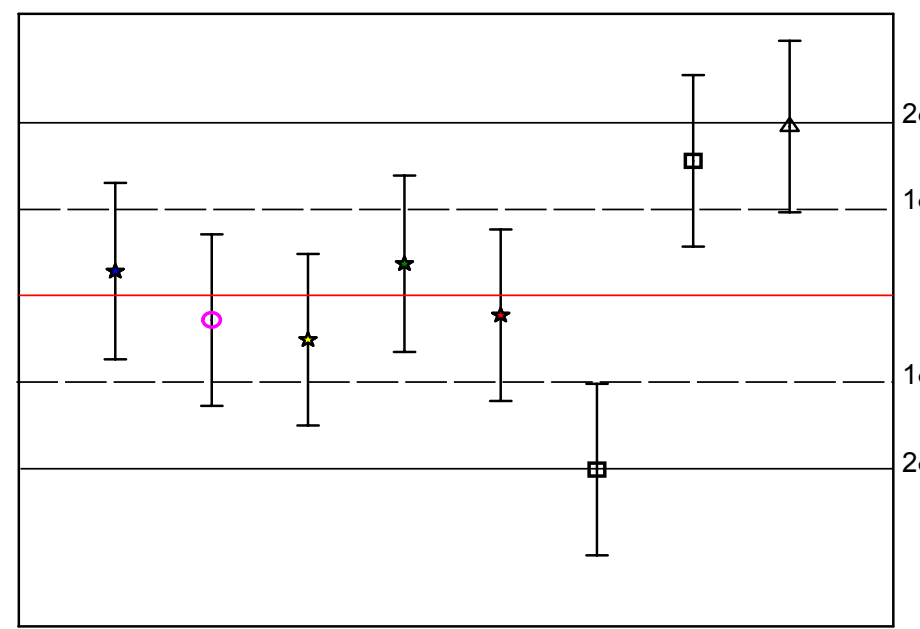

c) Intra species variability

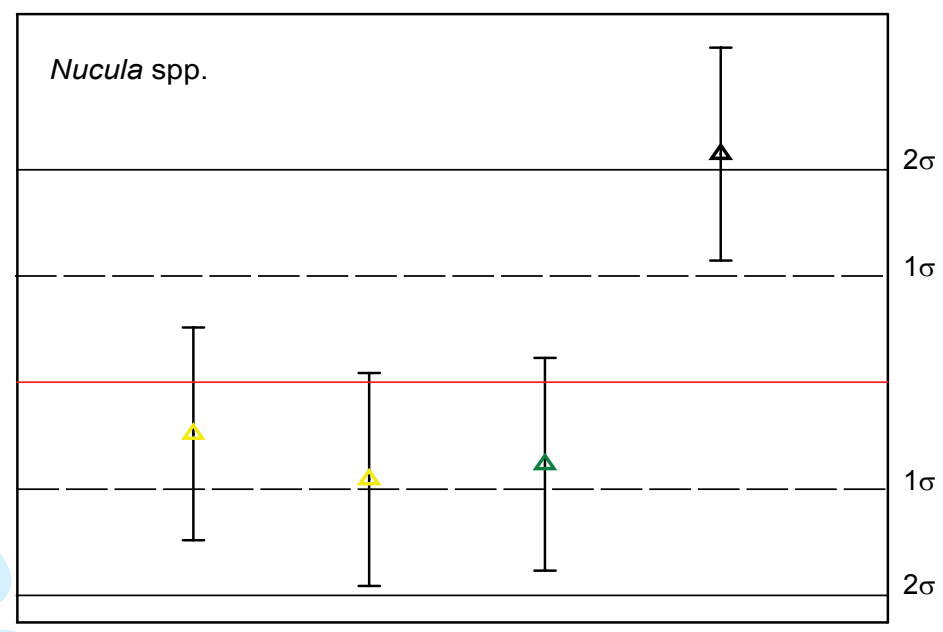

- Mixed feeders

- Suspension feeders

- Depositfeeders

Symbiont bearer

$\star$ Average ${ }^{14}$ Cage

Legend

Shetland
Cromarty
Forth
Minch
Hebrides
Faroes

